\title{
Comparison of the biology, dynamics, and secondary production of Talorchestia brito (Amphipoda, Talitridae) in Atlantic (Portugal) and Mediterranean (Tunisia) populations
}

\author{
S.C. Gonçalves ${ }^{\mathrm{a}, *}$, J.C. Marques ${ }^{\mathrm{b}}$, M.A. Pardal ${ }^{\mathrm{b}}$, \\ M.F. Bouslama ${ }^{\mathrm{c}}$, M. El Gtari ${ }^{\mathrm{c}}$, F. Charfi-Cheikhrouha ${ }^{\mathrm{c}}$ \\ ${ }^{a}$ ESTM - Escola Superior de Tecnologia do Mar, Santuário de Nossa Senhora dos Remédios apartado 126, 2524-909 Peniche, Portugal \\ ${ }^{\mathrm{b}} I M A R$ - Institute of Marine Research, Department of Zoology, Faculty of Sciences and Technology, \\ University of Coimbra, 3004-517 Coimbra, Portugal \\ ${ }^{\mathrm{c}}$ Faculté des Sciences de Tunis, Departement de Biologie, Laboratoire de Bio-Ecologie et Systématique Evolutive, \\ Campus Universitaire, 2092 Manar II, Tunisia
}

Received 24 February 2003; accepted 21 July 2003

\begin{abstract}
The biology, population dynamics, and production of Talorchestia brito were studied at two sandy beaches located on the Atlantic (Portugal) and on the Mediterranean (Tunisia) coasts, respectively. The seasonal variation in abundance and the overall densities were similar in both populations. Reproduction occurred from February to September in the Atlantic, and from March to early November in the Mediterranean. The sex ratio was male biased in the Atlantic, and female biased in the Mediterranean. Based on data from the Atlantic population, both abundance and the proportion of reproductive females were positively correlated with temperature, while the proportion of juveniles in the population was positively correlated with temperature and sediment moisture. On average, individuals from the Atlantic were larger than the ones from the Mediterranean. Life span was estimated at six to nine months in the Atlantic, and five to eight months in the Mediterranean. Talorchestia brito was shown to be a semiannual species, with iteroparous females producing two broods per year, and exhibited a bivoltine life cycle. The minimum age required for males' and females' sexual differentiation and for female sexual maturation was shorter in the Mediterranean. Growth production $(P)$ was estimated at $0.19 \mathrm{~g} \mathrm{~m}^{-2} \mathrm{y}^{-1}$ ash free dry weight (AFDW; $4.3 \mathrm{~kJ} \mathrm{~m}^{-2} \mathrm{y}^{-1}$ ) in the Atlantic population, and $0.217 \mathrm{~g} \mathrm{~m}^{-2} \mathrm{y}^{-1}$ AFDW $\left(4.9 \mathrm{~kJ} \mathrm{~m}^{-2} \mathrm{y}^{-1}\right)$ in the Mediterranean one. Elimination production $(E)$ was estimated at $0.35 \mathrm{~g} \mathrm{~m}^{-2} \mathrm{y}^{-1} \mathrm{AFDW}\left(7.9 \mathrm{~kJ} \mathrm{~m}^{-2} \mathrm{y}^{-1}\right)$ in the Atlantic, and $0.28 \mathrm{~g} \mathrm{~m}^{-2} \mathrm{y}^{-1} \operatorname{AFDW}\left(6.3 \mathrm{~kJ} \mathrm{~m}^{-2} \mathrm{y}^{-1}\right)$ in the Mediterranean. The average annual biomass $(\bar{B})$ (standing stock) was estimated at $0.032 \mathrm{~g} \mathrm{~m}^{-2}$ in the Atlantic beach, and $0.029 \mathrm{~g} \mathrm{~m}^{-2}$ in the Mediterranean one, resulting, respectively, in $P / \bar{B}$ ratios of 5.9 and 7.5 and $E / \bar{B}$ ratios of 10.8 and 9.6. Like other talitrids, T. brito exhibited geographic variation in morphometrical characteristics, sex ratio, growth rates, life span, and reproduction period, with the Atlantic population presenting a slower life history. (C) 2003 Elsevier Ltd. All rights reserved.
\end{abstract}

Keywords: Talorchestia brito; biology; population dynamics; geographical variation; Atlantic; Mediterranean; sandy beaches

\section{Introduction}

Talitrid amphipods constitute one of the dominant groups in sandy beach fauna (Dahl, 1945, 1952; McLachlan and Jaramillo, 1995), exhibiting a dynamic equilibrium with a changing environment. Talitrids' ecological relevance has justified worldwide studies, for instance with regard to their behavioural plasticity (e.g.

\footnotetext{
* Corresponding author.

E-mail address: scgoncalves@netvisao.pt (S.C. Gonçalves).
}

Scapini et al., 1993, 1995; Scapini and Fasinella, 1990; Mezzetti et al., 1994), factors influencing their spatial distribution and oriented movements in sandy beaches (e.g. Borgioli et al., 1999; Scapini et al., 1999; Scapini and Quochi, 1992), their behavioural strategies (e.g. Fallaci et al., 1999), genetic comparisons between populations (De Matthaeis et al., 1995; Bulnheim and Schwenzer, 1999), bioaccumulation by talitrids and their role in biomonitoring (e.g. Rainbow et al., 1989; Moore et al., 1991; Fialkowski et al., 2000). 
Talitrids' reproductive strategies and their contribution to the energy balance in beach ecosystems are, however, still poorly understood. There are few studies on talitrids' population biology (e.g. David, 1936; Palluault, 1954; Williams, 1978; Elkaïm et al., 1985; Van Senus, 1988; Wildish, 1988; Marsden, 1991a; Jones and Wigham, 1993; Persson, 1999), and even less on their secondary production (e.g. Van Senus and McLachlan, 1986; Cardoso and Veloso, 1996; O'Hanlon and Bolger, 1997; Marques et al., 2003). Moreover, most of these studies refer to different species at different sites, and very few really compare the life history features of the same species on geographically distinct beaches. Since different beaches offer diverse environmental conditions (e.g. temperatures, food resources, humidity, exposure to predators, substrate characteristics, exposure to waves and tidal excursions), different biological features are to be expected, as illustrated by a recent study on Talitrus saltator (Marques et al., 2003).

The sandhopper Talorchestia brito is widely distributed along the European Atlantic coast and on Western Mediterranean, occurring on more or less exposed beaches, often sympatrically with Talitrus saltator. With the exception of some short notes on its ecology (Lagardère, 1966; Vader, 1970), there were no studies on T. brito's biology, population dynamics and secondary production. In the present work these issues are analysed through a comparative study of two populations, respectively, from the Atlantic and the Mediterranean.

\section{Materials and methods}

\subsection{Study sites}

Two sets of data were provided by samples collected at two sandy beaches: Quiaios $\left(40^{\circ} 12^{\prime} 21^{\prime \prime} \mathrm{N}\right.$ $8^{\circ} 53^{\prime} 48^{\prime \prime} \mathrm{W}$ ), on the western coast of Portugal (Atlantic), and Zouara $\left(37^{\circ} 0^{\prime} 41^{\prime \prime} \mathrm{N} 08^{\circ} 53^{\prime} 26^{\prime \prime} \mathrm{E}\right)$, on the north western coast of Tunisia (Mediterranean) (Fig. 1). Both study sites are relatively undisturbed beaches where the input of beach debris was limited. The main differences between the two study sites are summarised in Table 1 . More extensive details regarding the characteristics of these two beaches, including the identification of existing and potential human impacts and pressures are provided in a previous paper (Marques et al., 2003).

\subsection{Sampling programme}

Quantitative samples were taken from the sandy beach communities at the two study sites. The sampling

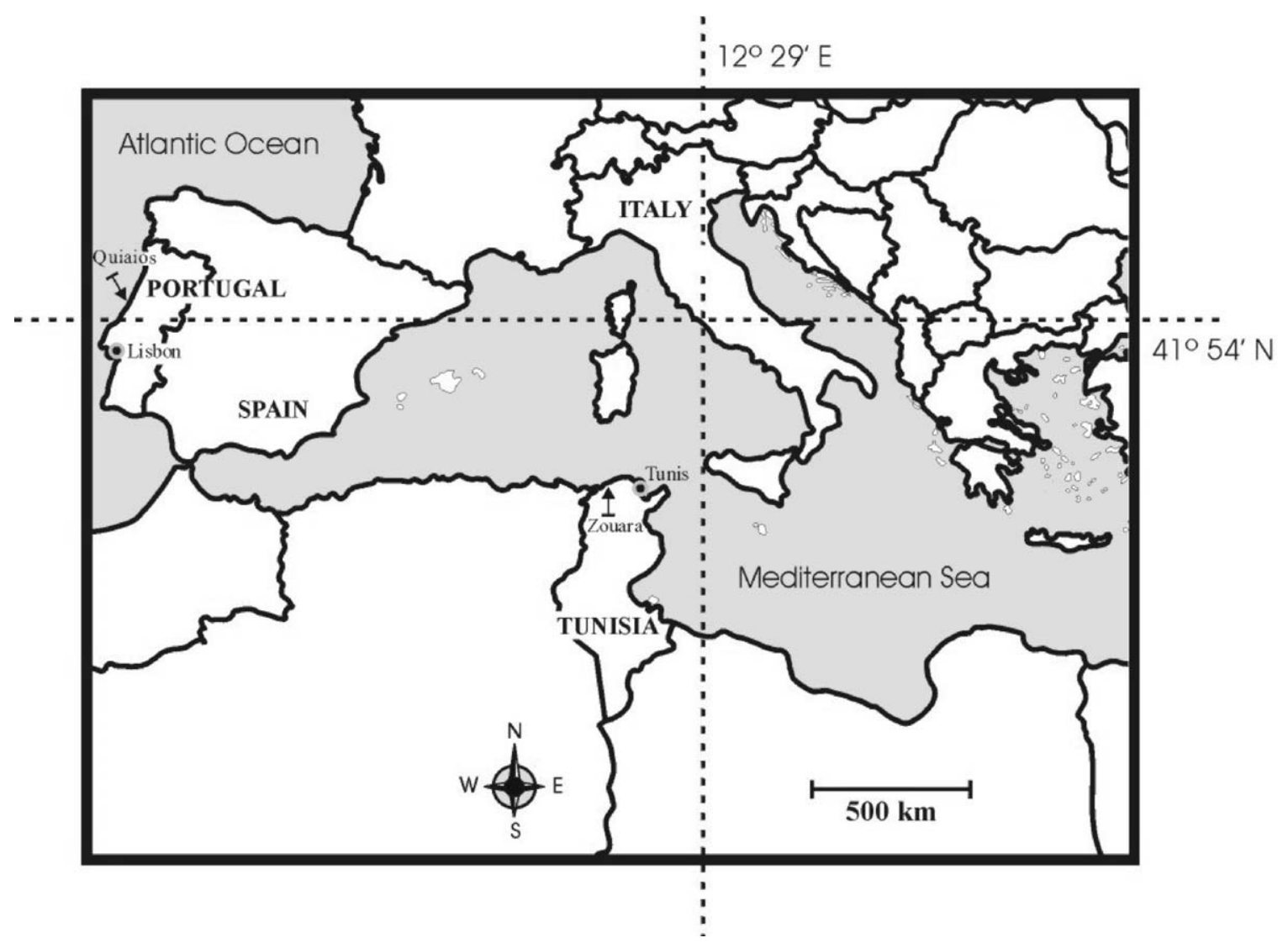

Fig. 1. Location of the two sampling stations: Quiaios (Atlantic, western coast of Portugal) and Zouara (north western coast of Tunisia). 
Table 1

Differences observed between the two sandy beaches used as sampling sites

\begin{tabular}{|c|c|c|}
\hline Characteristic & $\begin{array}{l}\text { Quiaios } \\
\text { (Atlantic) }\end{array}$ & $\begin{array}{l}\text { Zouara } \\
\text { (Mediterranean) }\end{array}$ \\
\hline $\begin{array}{l}\text { Width of the } \\
\text { eulittoral zone (m) }\end{array}$ & 100 & 50 \\
\hline Average slope $(\%)$ & 2 & 3 \\
\hline Tidal range $(\mathrm{m})$ & $2-3.5$ & $0.1-0.2$ \\
\hline $\begin{array}{l}\text { Extension of the } \\
\text { intertidal area }\end{array}$ & $\begin{array}{l}\text { Neap tides: } 50 \mathrm{~m} \\
\text { Spring tides: } 75 \mathrm{~m}\end{array}$ & $\begin{array}{c}\text { Tides frequently hidden } \\
\text { by local wave action }\end{array}$ \\
\hline Other $(\mathrm{m})$ & $\begin{array}{l}\text { Foredune } \\
\text { height: } 2.5-3\end{array}$ & $\begin{array}{l}\text { First dune belt } \\
\text { height: } 20\end{array}$ \\
\hline
\end{tabular}

period lasted from January 1999 to June 2000 at Quiaios (Atlantic) and from December 1998 to December 1999 at Zouara (Mediterranean), respectively, 18 and 12 months. Although logistic constraints did not allow sampling exactly at the same time, there was a significant time overlap of field work at the two sites. The study period was longer at Quiaios in order to obtain a larger data set, which was considered necessary for further modelling development. Two teams (Tunisian and Portuguese) were involved in the sampling effort, and the field methodologies were previously inter-calibrated through reciprocal visits to both sites. The sampling programme followed the field work protocol already described by Marques et al. (2003).

The influence of environmental factors on the Talorchestia brito population was investigated at Quiaios. For this purpose, debris quantity (potential food $\mathrm{g} \mathrm{m}^{-2}$ ), organic matter as ash free dry weight (AFDW) and sediment moisture were determined according to the procedures described in Marques et al. (2003). Meteorological data during the study period were obtained from the nearest weather station, including average daily precipitation, maximum and minimum daily temperatures, visibility, cloudiness, wave height, wave period, and wind velocity.

\subsection{Laboratory procedures}

Field samples were processed at two laboratories in Portugal (Coimbra) and Tunisia (Tunis), respectively. The laboratory procedures used for the biometric and biological analysis, namely cephalic length (CL) measurements, individuals sexing, and classification of embryos are described in Marques et al. (2003). When necessary, total length (TL) was estimated from CL through the following equations:

$$
\begin{aligned}
\mathrm{TL} & =-3.22705176+13.02842421 \times \mathrm{CL}, \\
n & =164, r=0.927-\text { for the Quiaios population } \\
\mathrm{TL} & =-0.623061696+9.490905465 \times \mathrm{CL} \\
n & =148, r=0.89-\text { for the Zouara population. }
\end{aligned}
$$

The quantitative nature of the field sampling procedure together with animals' manipulation caused gravid (mature) females to drop an undetermined number of embryos from brood pouches, which made any further significant statistical analysis unrealistic regarding brood mortality and egg dimensions.

The relationships between length and weight of the individuals were analysed each season (spring, summer, autumn, and winter). For this purpose 150-200 randomly sampled specimens were weighed each time (AFDW, after combustion at $450{ }^{\circ} \mathrm{C}$ during $3 \mathrm{~h}$ ) with a $10^{-5} \mathrm{mg}$ precision, following the same approach described in Marques et al. (2003). Four significantly different (analysis of variance; $p<0.05$ ) seasonal equations were estimated (Table 2).

\subsection{Data analysis}

The spatial distribution of the studied populations was analysed using the index $I=S^{2} / \bar{X}$ according to Elliot (1977). Multiple regression models were developed based on data from Quiaios (Atlantic), correlating density, sex ratio, percentage of gravid females, and percentage of juveniles in the population with physicochemical environmental factors. As in a previous study (Marques et al., 2003), the models were fitted with data following the Stepwise Regression method using the MINITAB 12.2 software package.

Field growth rates were estimated by tracking modal distributions recognisable in successive sample dates through size-frequency analysis, following a methodology successfully used before (Marques et al., 1994, 2003; Lillebø et al., 1999; Pardal et al., 2000). Modal distributions are in this case assumed to result from pulses in recruitment, conventionally referred to as cohorts. Computations were performed using the ANAMOD software (Nogueira, personal communication), based on the probability paper method (Harding, 1949), as performed by Cassie $(1954,1963)$. The reliability of the method was tested employing both the $\chi^{2}$ and $G$ tests $(p \leq 0.05)$.

Field growth data were fitted to the Bertalanffy growth function (VBGF) with seasonal oscillation,

Estimated seasonal length and weight equations for Talorchestia brito at the two sampling sites

\begin{tabular}{llll}
\hline & Winter & Spring & Summer \\
\hline Atlantic & AFDW $=0.003256 \mathrm{CL}^{3.98217}$ & AFDW $=0.002658 \mathrm{CL}^{4.18694}$ & AFDW $=0.002323 \mathrm{CL}^{3.92355}$ \\
Mediterranean & AFDW $=0.003365 \mathrm{CL}^{3.97211}$ & AFDW $=0.002762 \mathrm{CL}^{4.15690}$ & AFDW $=0.00412 \mathrm{CL}^{4.94227}$ \\
\hline
\end{tabular}


according to a model proposed by Gaschütz et al. (1980), and previously applied with satisfactory results (e.g. Marques et al., 1994; Achouri et al., 2003):

$$
\begin{aligned}
L_{t}= & L_{\infty}\left(1-\exp \left\{-\left[K D\left(t-t_{0}\right)+C(K D / 2 \pi)\right.\right.\right. \\
& \left.\left.\left.\times \sin 2 \pi\left(t-t_{\mathrm{s}}\right)\right]\right\}\right)
\end{aligned}
$$

where $L_{t}$ is the length of the organism at a given moment $t ; L_{\infty}$ the maximum possible length of the organism; $t$ the given time instant; $t_{0}$ the instant in which the organism would have a length $=0 ; K$ the intrinsic growth rate; $C$ the constant, variable between 0 (e.g. tropical organisms where the seasonal variance is minimum or absent) and 1 (e.g. cold temperate organisms, where winter growth is reduced or absent); and $D$ is assumed as 1 since there is no information regarding the metabolism of Talorchestia brito.

Growth $(P)$ and elimination $(E)$ productions, as well as $P / \bar{B}$ and $E / \bar{B}$ ratios, were estimated based upon cohort recognition, according to a method derived by Allen (1971) and fully described in a previous paper (Marques et al., 2003).

\section{Results}

\subsection{Spatial distribution and abundance}

The two studied populations presented contagious spatial distribution, corresponding to values of $I$ always higher than 1 (Elliot, 1977). At both sites the greater number of individuals were concentrated in the intertidal zone, almost always just below high water mark, occupying a more restricted and seaward area than the sympatric species Talitrus saltator, also present.

The seasonal variation in abundance followed a similar pattern at the two study sites: densities always reached the lowest values in the winter, followed by a rapid increase from early spring up to a maximum in June. Then a slight decrease occurred during the summer, followed by a second peak in October, even stronger than the first one at Zouara, and a gradual decrease from late autumn until the next winter (Fig. 2).

\subsection{Period of reproduction and sex ratio}

The occurrence of reproductive females (Fig. 3A and B), consisting of both gravid and mature females, and the appearance of new juvenile cohorts in the population (Figs. 3A, B and 4 for some examples) allowed identification of the reproductive period. Recruitment took place from February to September at Quiaios, with new cohorts being recognised in February, April, June, July, August and September. In Tunisia, the reproductive period was longer, from March to early November, with new cohorts detected in March, April, July, August, September and November (Fig. 5).
The percentage of juveniles in the population (Fig. 3A, B) showed a seasonal pattern of variation at Quiaios, with a first peak in late spring, followed by a small decrease in early summer, a second and strongest peak in August and September, another short drop in early autumn, and a last peak in October and November, just before winter. Although reproduction started in early February, the strongest breeding took place from late spring to early autumn, which is consistent with the variation in the proportion of reproductive females (Fig. 3A). At Zouara, although data suggest that recruitment was stronger during summer, the percentage of juveniles in the population does not show any clear pattern of variation (Fig. 3B).

Sex ratios (males/females) were clearly different in the two populations (Fig. 3C, D). While in Quiaios the sex ratio was clearly male biased (average $1.2: 1$ ), except for a short time in spring (April/May) and autumn (September/October), in Zouara the population was clearly dominated by females (average $0.453: 1$ ), except in middle spring (April/May).

\subsection{Influence of environmental factors on the population structure}

Multiple regression models were established using complete data sets on the biological variables (population density, population biomass, sex ratio, percentage of juveniles in the population, percentage of reproductive females over the total female population) and physicochemical factors determined at each sampling date in Quiaios. The average values and range of variation of physicochemical factors in Quiaios during the whole 18 month study period are summarised in Table 3 .

Stepwise multiple regression analysis revealed that population density $(D)$ and the proportion of reproductive females $\left(P_{\text {Frep }}\right)$ were positively correlated with temperature $(T)$. Moreover, the percentage of juveniles in the population $\left(P_{\mathrm{J}}\right)$ was positively correlated with temperature $(T)$ and sediment moisture (SM). The following regression models describe these relations:

$$
\begin{aligned}
& \operatorname{Ln}(1+D)=1.22+0.101 T\left(r^{2}=0.4 ; p=0.000\right) \\
& P_{\text {Frep }}=-13.8+1.72 T\left(r^{2}=0.495 ; p=0.000\right) \\
& P_{\mathrm{J}}=-24.6+2.60 T+4.79 \mathrm{SM}\left(r^{2}=0.51 ; p=0.000\right. \text { for }
\end{aligned}
$$

temperature and $p=0.022$ for sediment moisture).

\subsection{Field growth rates and life span}

Size-frequency polymodal distributions were analysed for recognisable cohorts (Fig. 4, for some 

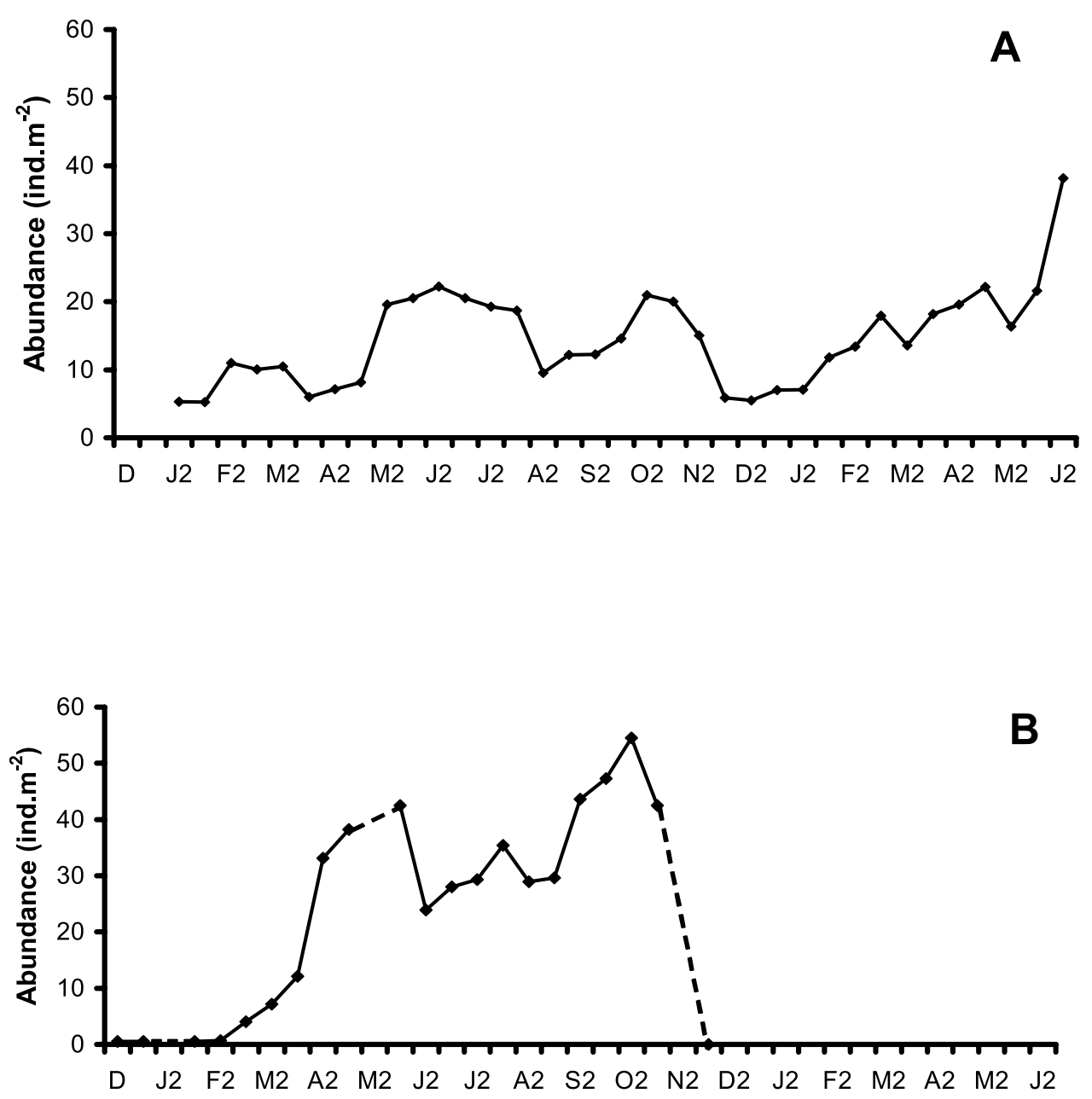

1999

2000

Fig. 2. Variation of Talorchestia brito population abundance. (A) Atlantic, western coast of Portugal (Quiaios); (B) Mediterranean, north western coast of Tunisia (Zouara). Sampling periodicity took place every 15 days. Broken lines indicate probable abundance evolution when data were insufficient due to sampling constraints.

examples). Three cohorts $(\mathrm{C} 1-\mathrm{C} 3)$ were identified in Quiaios at the first sampling date (21/01/99) (Fig. 4), and 10 new cohorts, presumably corresponding to new recruitments, were further identified during the 18 month study period (Fig. 5A) $\left(\chi^{2}\right.$ and $G$ tests not significant; $p \geq 0.05$ ). The population therefore produced six new cohorts in Quiaios during 1999 (C4-C9), recruiting between February and September, and four other new ones from February to June 2000 (C10, C11, $\mathrm{C} 12$, and $\mathrm{C} 13$, respectively), which confirmed the recruitment pattern.

At Zouara, the total duration of the study period was only 12 months. Four cohorts $(\mathrm{C} 1-\mathrm{C} 4)$ were recognised at the first sampling for which enough individuals were collected to perform modal analysis (16/03/99). Taking into account the average $\mathrm{CL}$ at the moment of detection, cohort C4 was assumed as new born. Additionally, six new distributions were detected in the next nine months (Fig. 4). The Zouara population produced therefore seven new cohorts during 1999 (C4-C10), recruiting between March and November (Fig. 5B). As expected, comparing the two populations, the rhythm of recruitment was higher in the Mediterranean.

Minimum and maximum average size of cohorts, respectively, at the moment of detection and of disappearance, varied as a function of study sites (Fig. 5). At Quiaios, the minimum average CL of new cohorts ranged from 0.46 (spring) to $0.6914 \mathrm{~mm}$ (late winter) (2.77-5.78 $\mathrm{mm} \mathrm{TL}$ ), while the maximum average CL ranged from 1.1826 to $1.52 \mathrm{~mm} \mathrm{CL}(12.18-16.58 \mathrm{~mm}$ TL). At Zouara, the minimum ranged from 0.4193 to $0.5023 \mathrm{~mm} \mathrm{CL}(3.36-4.14 \mathrm{~mm} \mathrm{TL})$, and the maximum from 1.1242-1.36 mm CL (10.05-12.28 mm TL). The Atlantic population therefore presented the largest newborn and the largest adult individuals, which is consistent with the known variation of Gammaridea life history patterns as a function of latitude (Wildish, 1982, 1988; Sainte-Marie, 1991). 

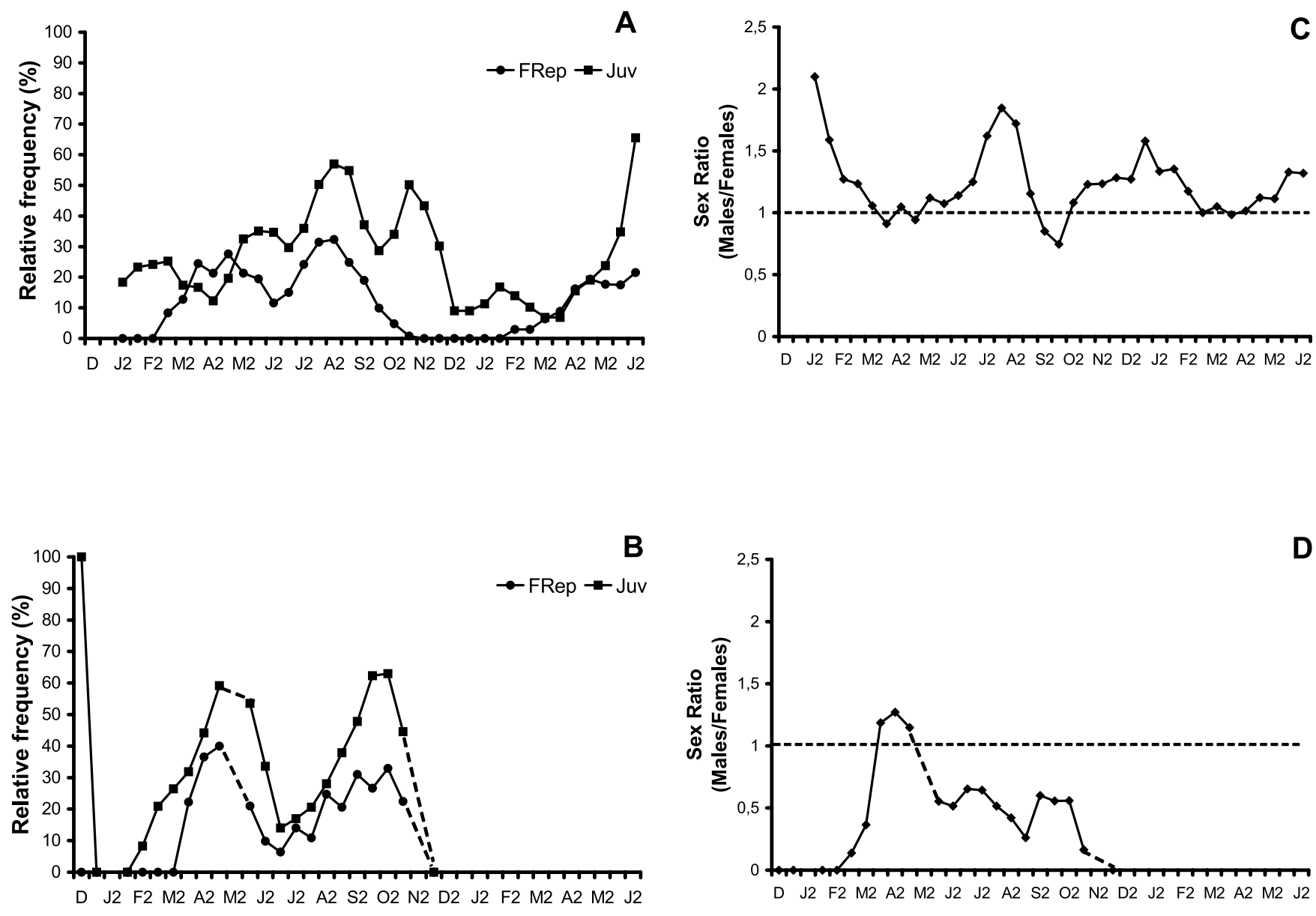

1999

2000

1999

2000

Fig. 3. Variation of biological features of Talorchestia brito. (A) Variation of reproductive females in the total female population, and of juveniles in the population, in the Atlantic; (B) variation of reproductive females in the total female population, and of juveniles in the population, in the Mediterranean; (C) variation of sex ratio in the Atlantic; (D) variation of sex ratio in the Mediterranean. Broken lines indicate probable evolution when data were insufficient due to sampling constraints.

Growth was continuous throughout life but growth rates varied as a function of size and temperature, being higher during early life stages, and apparently also during spring and summer (Fig. 5). This was a recognisable pattern at Quiaios, but less clear at Zouara. Life spans were estimated at six (spring or summer cohorts) to nine (autumn or winter cohorts) months for the Atlantic population and five (spring or summer cohorts) to eight (autumn or winter cohorts) months for the Mediterranean one (Table 4). Therefore, as a pattern, cohorts born in the beginning of the reproductive period showed a tendency to have shorter lives, while cohorts born near the end of the reproductive period overwintered and bred in the next breeding season (Fig. 5), exhibiting longer life spans.

Growth data sets from the two sites were used to calibrate the growth model, providing a different set of parameters in each case (Fig. 6). According to the model: (a) growth was faster in the early life stage phases
(Fig. 6); (b) the minimum period necessary for male sexual differentiation after birth was estimated at approximately five weeks in Quiaios and four weeks in Zouara; (c) the period required by females to attain sexual differentiation after birth was estimated at approximately seven weeks in Quiaios, and five weeks at Zouara; (d) the period necessary for female sexual maturation after birth was estimated at approximately fifteen weeks in Quiaios and ten weeks at Zouara (Table 4). Sexual differentiation therefore tended to occur earlier in males than in females. Female sexual differentiation and sexual maturation moreover occurred earlier in the Mediterranean population than in the Atlantic one.

\subsection{Life cycle}

Size-frequency analysis (Fig. 4) allowed determination of the cohorts to which males and reproductive females belonged. The analyses of probable parental 


\section{Atlantic}
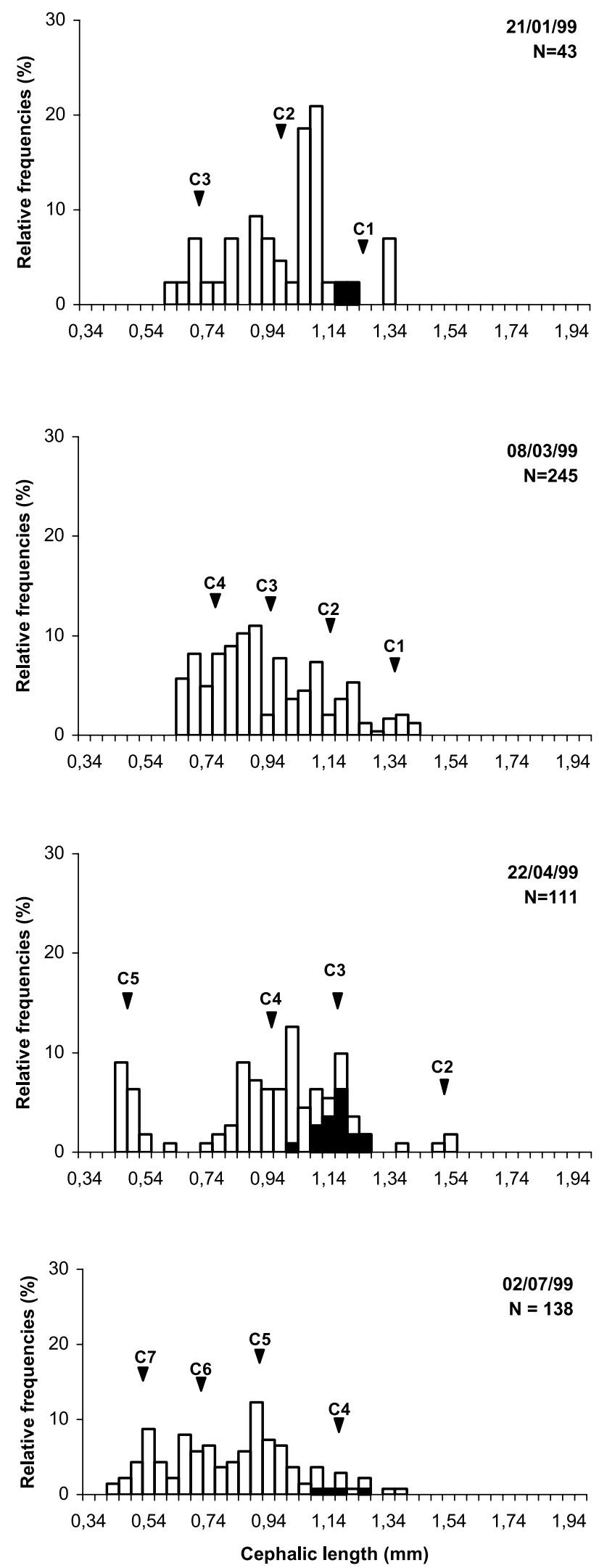

Mediterranean
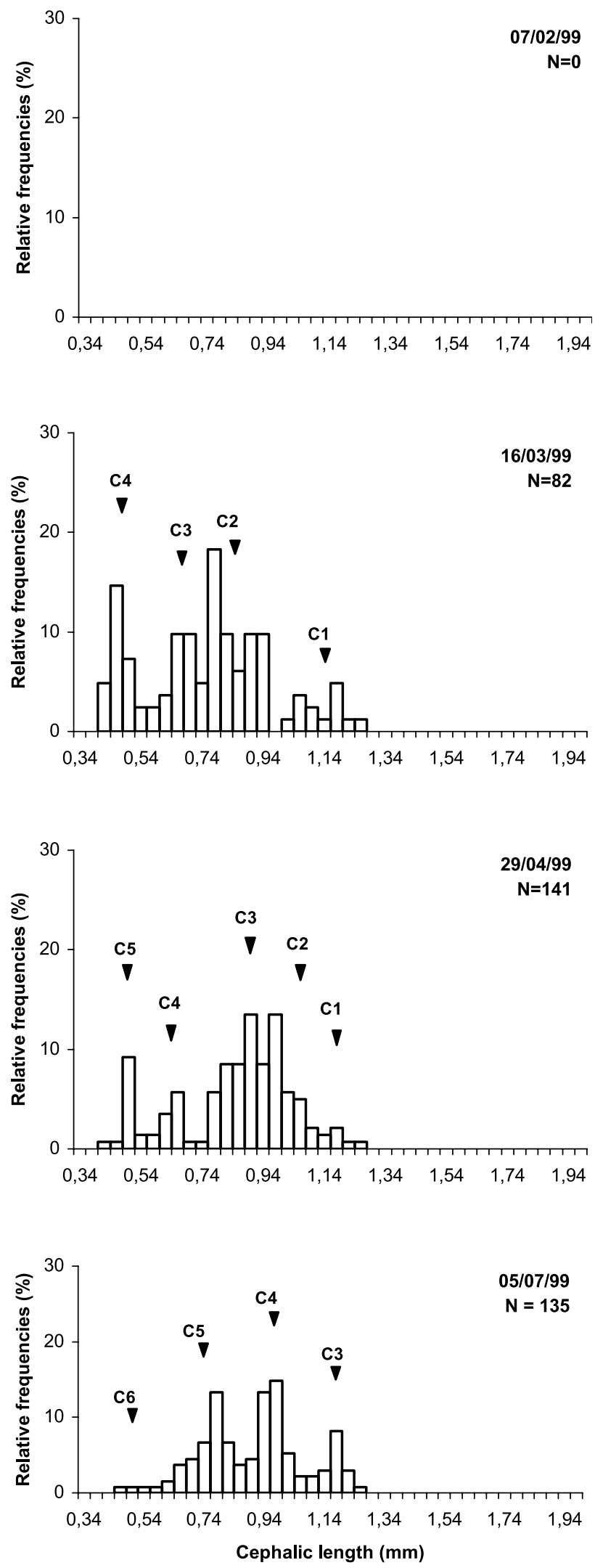

Fig. 4. Size-frequency distribution of Talorchestia brito at the Atlantic (Quiaios) and at the Mediterranean (Zouara). Sampling dates are indicated. $N=$ number of measured individuals. Arrowheads indicate average cephalic length of the numbered cohorts. Black areas indicate gravid females. 


\section{Atlantic}
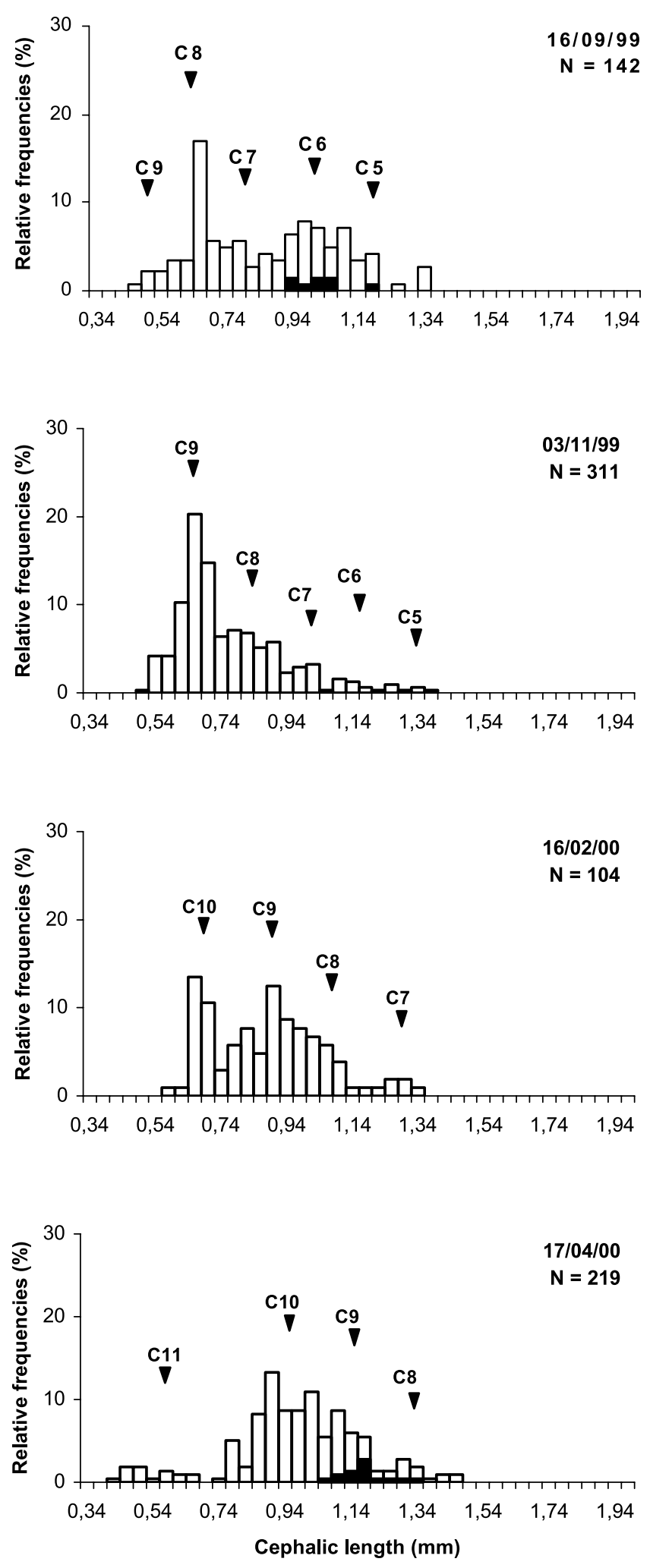

\section{Mediterranean}
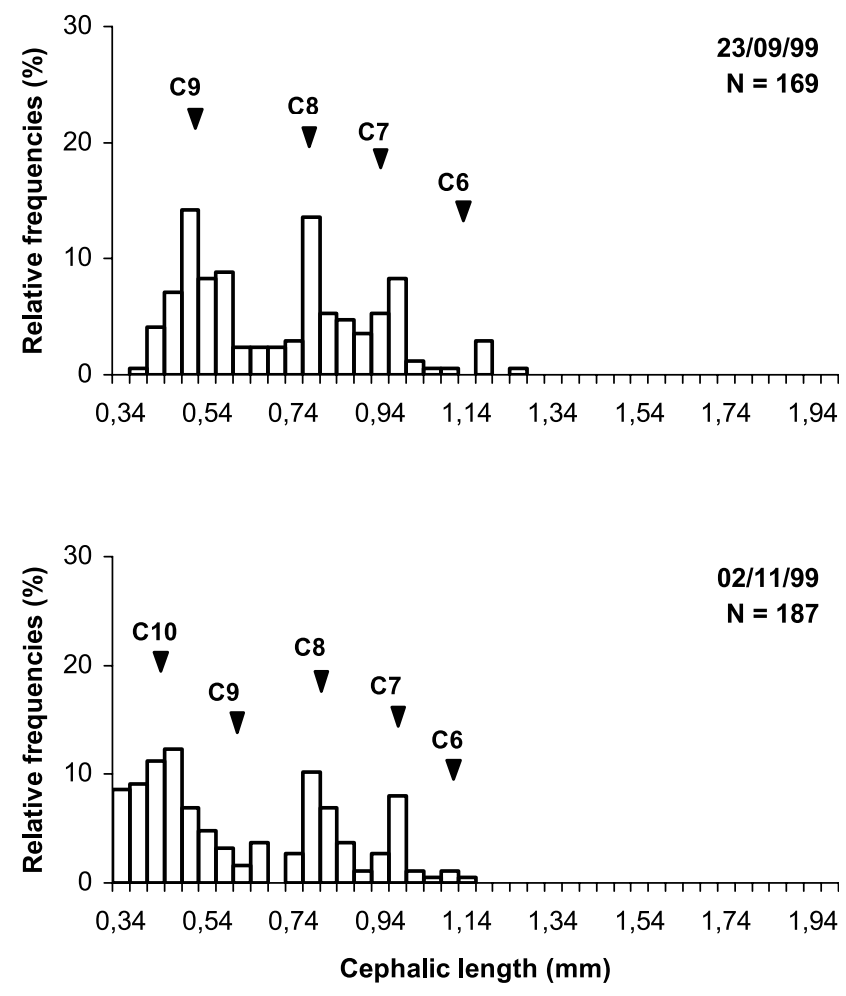

Fig. 4 (continued) 

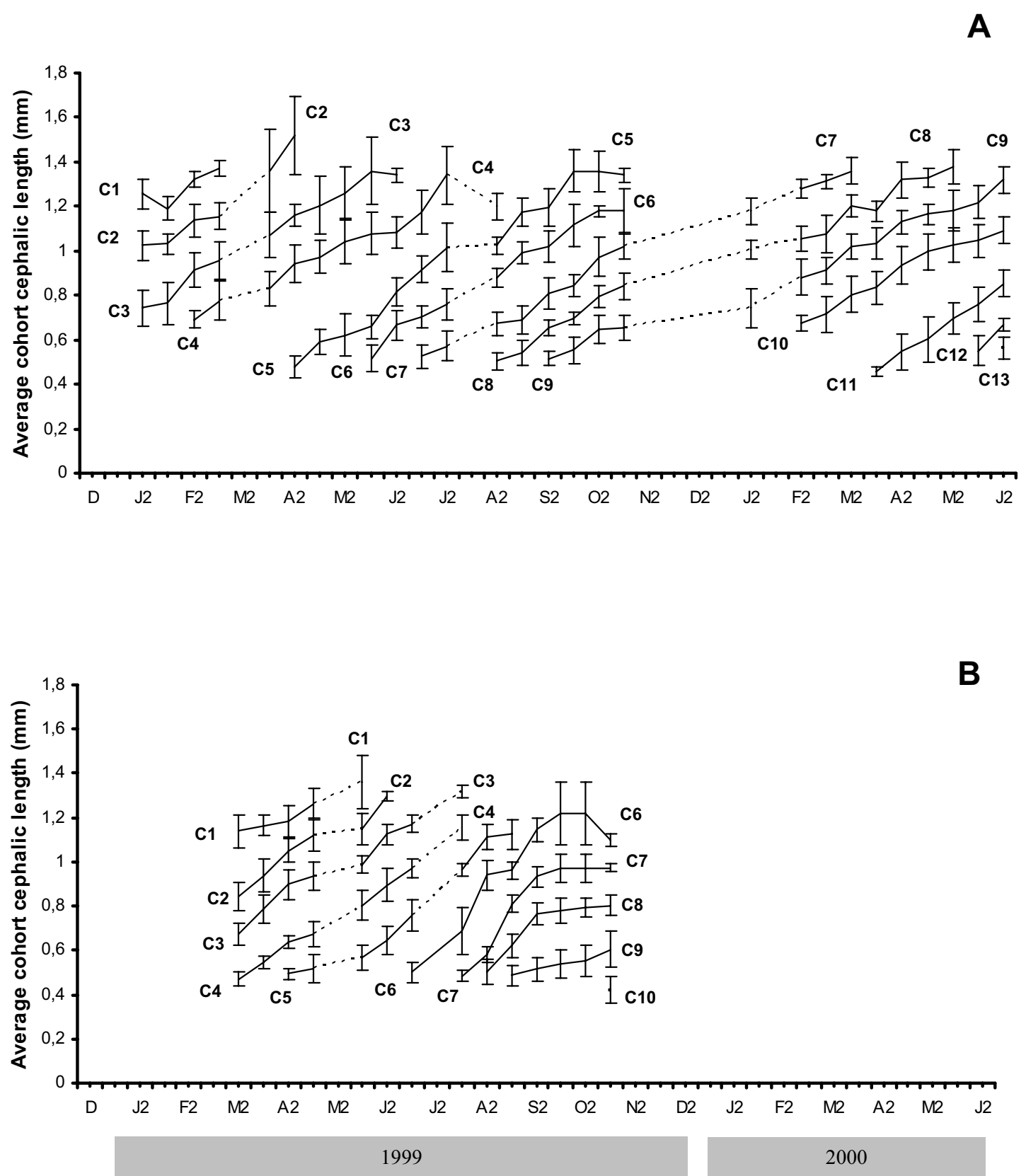

Fig. 5. Estimated growth and life span (field growth data) of Talorchestia brito cohorts (average cephalic length \pm standard deviation) at the two study sites. Broken lines indicate probable cohort evolution through time. (A) Atlantic, western coast of Portugal (Quiaios); (B) Mediterranean, north western coast of Tunisia (Zouara).

relations between the existing cohorts and the new ones recruited during the study period also allowed comparison of the life cycle characteristics of the two populations (Fig. 7).

As a pattern, cohorts born in the beginning of the reproductive period, i.e. late winter (Quiaios) and spring (Quiaios and Zouara), reproduced in the same season, exhibiting shorter life spans and most probably not surviving the winter. On the contrary, cohorts born later in the breeding season, i.e. summer and autumn, lived longer, over wintering, becoming sexually active, and breeding only in the next spring. Both populations appeared to produce two generations within the same reproductive period. Females from each cohort breed apparently twice a year (Fig. 7). At both sites, therefore, Talorchestia brito (a) behaves like a semiannual species, with iteroparous females producing two broods per year and (b) exhibits a bivoltine life cycle, with populations producing two generations per year (Table 4).

\subsection{Production estimates}

Length-weight relationships were used in production estimates. Growth production $(P)$ was estimated at 
Table 3

Average $(A)$ values and standard deviation (SD) of physicochemical factors at Quiaios beach (western coast of Portugal) regarding the period from January 1999 to June 2000

\begin{tabular}{lrr}
\hline & \multicolumn{1}{c}{ A } & SD \\
\hline Temperature $\left({ }^{\circ} \mathrm{C}\right)$ & 15.02 & 4.91 \\
Precipitation $(\mathrm{mm})$ & 2.36 & 5.49 \\
Sediment moisture $(\%)$ & 2.64 & 0.95 \\
Organic matter content in sediments $(\%)$ & 0.19 & 0.35 \\
Detritus $\left(\mathrm{g} \mathrm{m}^{-2}\right)$ & 2.02 & 1.82 \\
Wind velocity & 4.05 & 3.03 \\
Cloudiness & 3.97 & 2.68 \\
Visibility & 6.11 & 1.03 \\
Wave height & 0.06 & 0.33 \\
Wave period & 0.12 & 0.65 \\
\hline
\end{tabular}

$0.19 \mathrm{~g} \mathrm{~m}^{-2} \mathrm{y}^{-1}$ AFDW in Quiaios, and $0.217 \mathrm{~g} \mathrm{~m}^{-2} \mathrm{y}^{-1}$ AFDW in Zouara, which for talitrids is approximately equivalent to $4.3 \mathrm{~kJ} \mathrm{~m}^{-2} \mathrm{y}^{-1}$, and $4.9 \mathrm{~kJ} \mathrm{~m}^{-2} \mathrm{y}^{-1}$, respectively (Jørgensen et al., 1991). Elimination production $(E)$ was estimated at $0.35 \mathrm{~g} \mathrm{~m}^{-2} \mathrm{y}^{-1}$ AFDW (7.9 $\mathrm{kJ} \mathrm{m}^{-2} \mathrm{y}^{-1}$ ) in Quiaios, and $0.28 \mathrm{~g} \mathrm{~m}^{-2} \mathrm{y}^{-1}$ AFDW (6.3 $\mathrm{kJ} \mathrm{m}^{-2} \mathrm{y}^{-1}$ ) in Zouara (Table 4). The average annual biomass $(\bar{B})$ (standing stock) was estimated at $0.032 \mathrm{~g}$ $\mathrm{m}^{-2}$ in Quiaios, and $0.029 \mathrm{~g} \mathrm{~m}^{-2}$ in Zouara, resulting, respectively, in $P / \bar{B}$ ratios of 5.9 and 7.5 and $E / \bar{B}$ ratios of 10.8 and 9.6 (Table 4).

Growth and elimination productions were analysed with regard to their temporal variation (Fig. 8). In Quiaios, growth production $(P)$ was higher in autumn, while in Zouara it was roughly constant throughout the year. Variations in elimination production $(E)$ were

Table 4

Comparison of population characteristics of Talorchestia brito at the study sites with regard to biology, life cycle, and production, based on data produced in the present study

\begin{tabular}{|c|c|c|}
\hline Characteristic & $\begin{array}{l}\text { Quiaios } \\
\text { (Portugal) } \\
\text { Atlantic }\end{array}$ & $\begin{array}{l}\text { Zouara } \\
\text { (Tunisia) } \\
\text { Mediterranean }\end{array}$ \\
\hline Reproductive period & $\begin{array}{l}\text { February- } \\
\text { September }\end{array}$ & $\begin{array}{l}\text { March- } \\
\text { November }\end{array}$ \\
\hline Average sex ratio (ठ//९) & $1.2: 1$ & $0.453: 1$ \\
\hline $\begin{array}{l}\text { Age of males at sexual } \\
\text { differentiation (weeks) }\end{array}$ & \pm 5 & \pm 4 \\
\hline $\begin{array}{l}\text { Age of females at sexual } \\
\text { differentiation (weeks) }\end{array}$ & \pm 7 & \pm 5 \\
\hline $\begin{array}{l}\text { Age of females at sexual } \\
\text { maturation (weeks) }\end{array}$ & \pm 15 & \pm 10 \\
\hline Life span (months) & $6-9$ & $5-8$ \\
\hline Recruitment pattern & Bivoltine & Bivoltine \\
\hline $\begin{array}{l}\text { Growth production }(P) \\
\qquad\left(\mathrm{g} \mathrm{m}^{-2} \mathrm{y}^{-1}\right)\end{array}$ & 0.19 & 0.217 \\
\hline $\begin{array}{l}\text { Elimination production }(E) \\
\left(\mathrm{g} \mathrm{m}^{-2} \mathrm{y}^{-1}\right)\end{array}$ & 0.35 & 0.278 \\
\hline $\begin{array}{l}\text { Average annual biomass }(B) \\
\quad\left(\mathrm{g} \mathrm{m}^{-2}\right)\end{array}$ & 0.032 & 0.029 \\
\hline$P / B$ & 5.9 & 7.5 \\
\hline$E / B$ & 10.8 & 9.6 \\
\hline
\end{tabular}
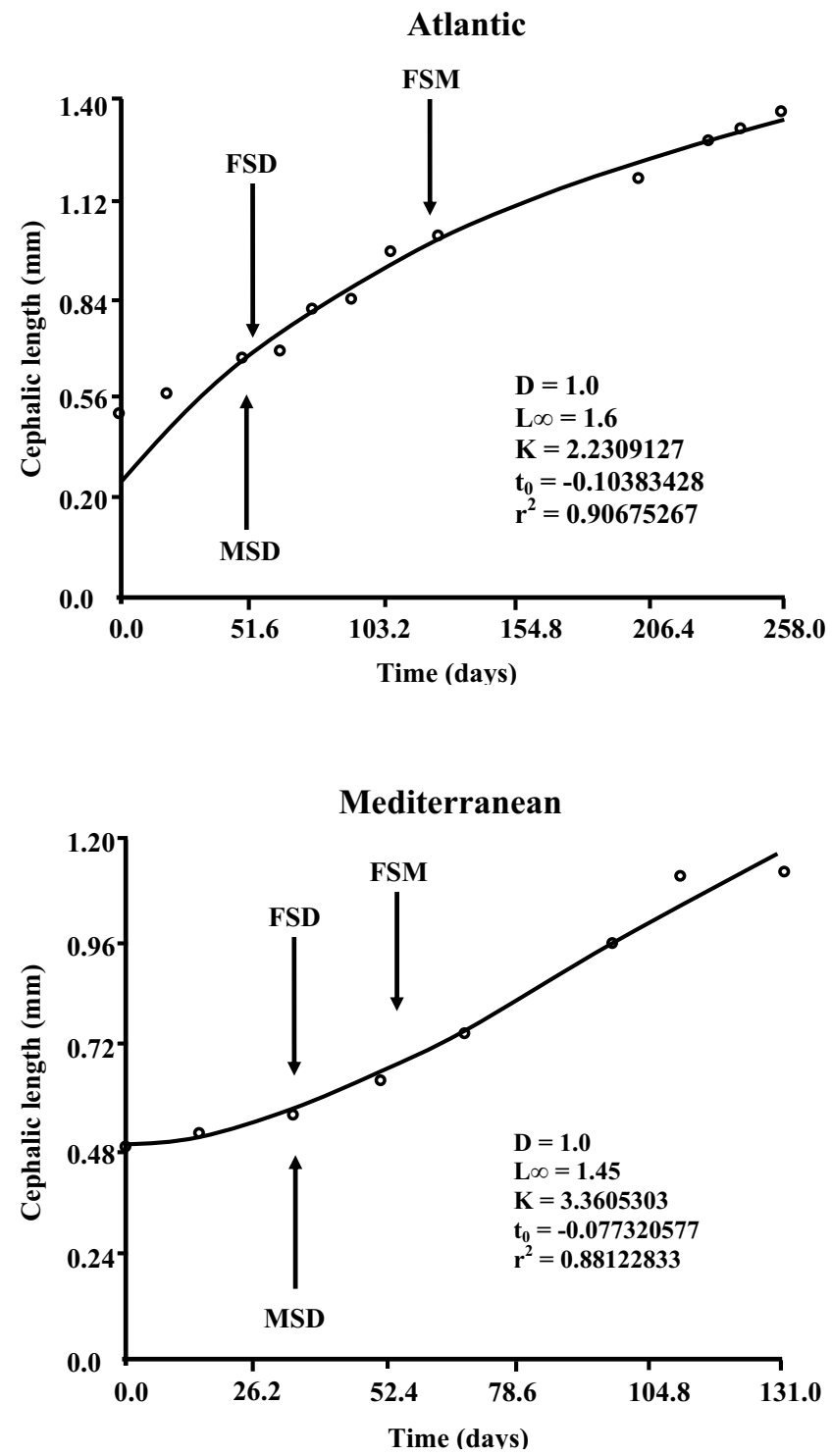

Fig. 6. Individual growth model (Gaschütz et al., 1980) of Talorchestia brito at the two study sites. The models were calibrated with field growth data from cohorts (plotted points). Model parameters are given; $r^{2}=$ correlation between predicted and observed values (see Section 2 for details). MSD: male's sexual differentiation; FSD: female's sexual differentiation; FSM: female's sexual maturation.

much stronger, with the highest values from spring to autumn in Quiaios, and during autumn in Zouara. A consistent comparison of the temporal patterns of variation nevertheless became difficult due to the lack of a bigger data set concerning the Zouara population.

\section{Discussion}

\subsection{Spatial distribution and population abundance}

Talorchestia brito showed an aggregated pattern of distribution. Since it feeds mainly on the interstitial flora 


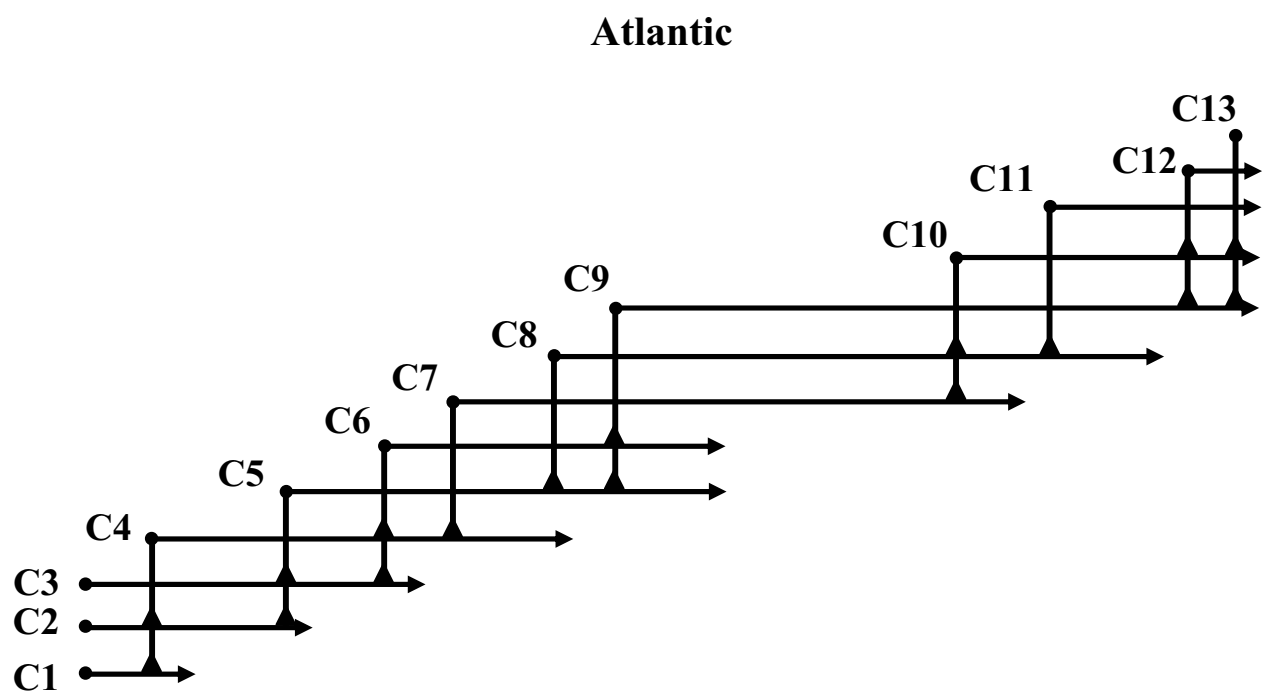

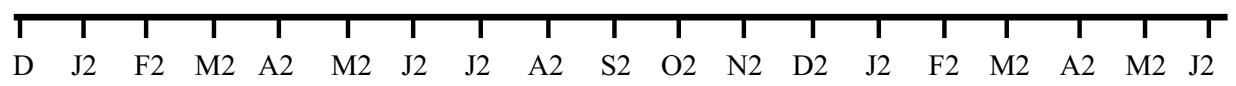

\section{Mediterranean}

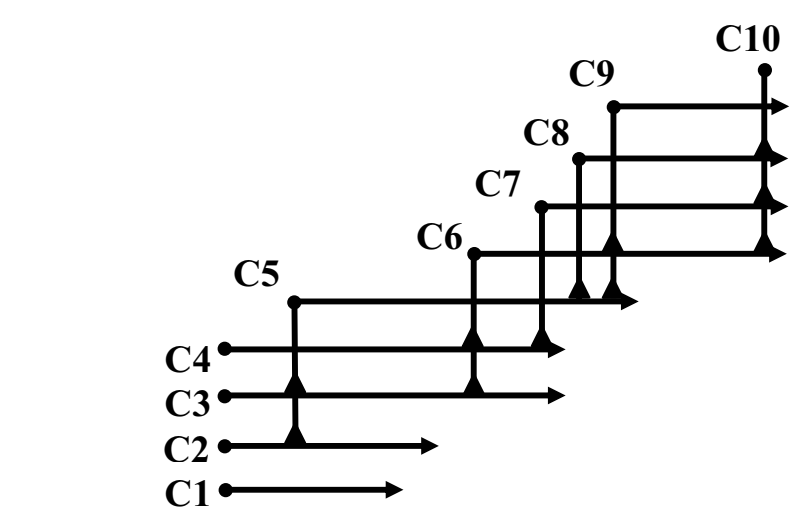

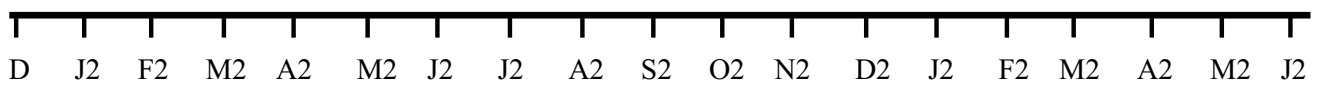

1999

2000

Fig. 7. Analysis of the recruitment pattern of Talorchestia brito at the two study sites. The horizontal arrows represent the period during which each cohort was followed during the study period, starting in the solid circles. The assumed contributions of each cohort are indicated (triangles).

(Vader, 1970) such patchy distribution may be related to the distribution of the stranded surf zone diatoms, as proposed by Colombini et al. (2002). The restricted diet of this species may also explain why, despite differences in the range of tidal excursions between the Atlantic and Mediterranean coasts, densities in Quiaios and Zouara populations were similar.

The seasonal variation in population abundance followed a comparable pattern in Quiaios and Zouara.
This reflects a similar population dynamics, despite differences in life history traits. In fact, the increase in density in spring, summer and early autumn is a natural consequence of recruitment, while the general decrease observed in late autumn results from the death of older individuals after the breeding season. Minimum abundances during winter obviously suggest that alongshore and sediment depth distributions vary as a response to environmental constraints 

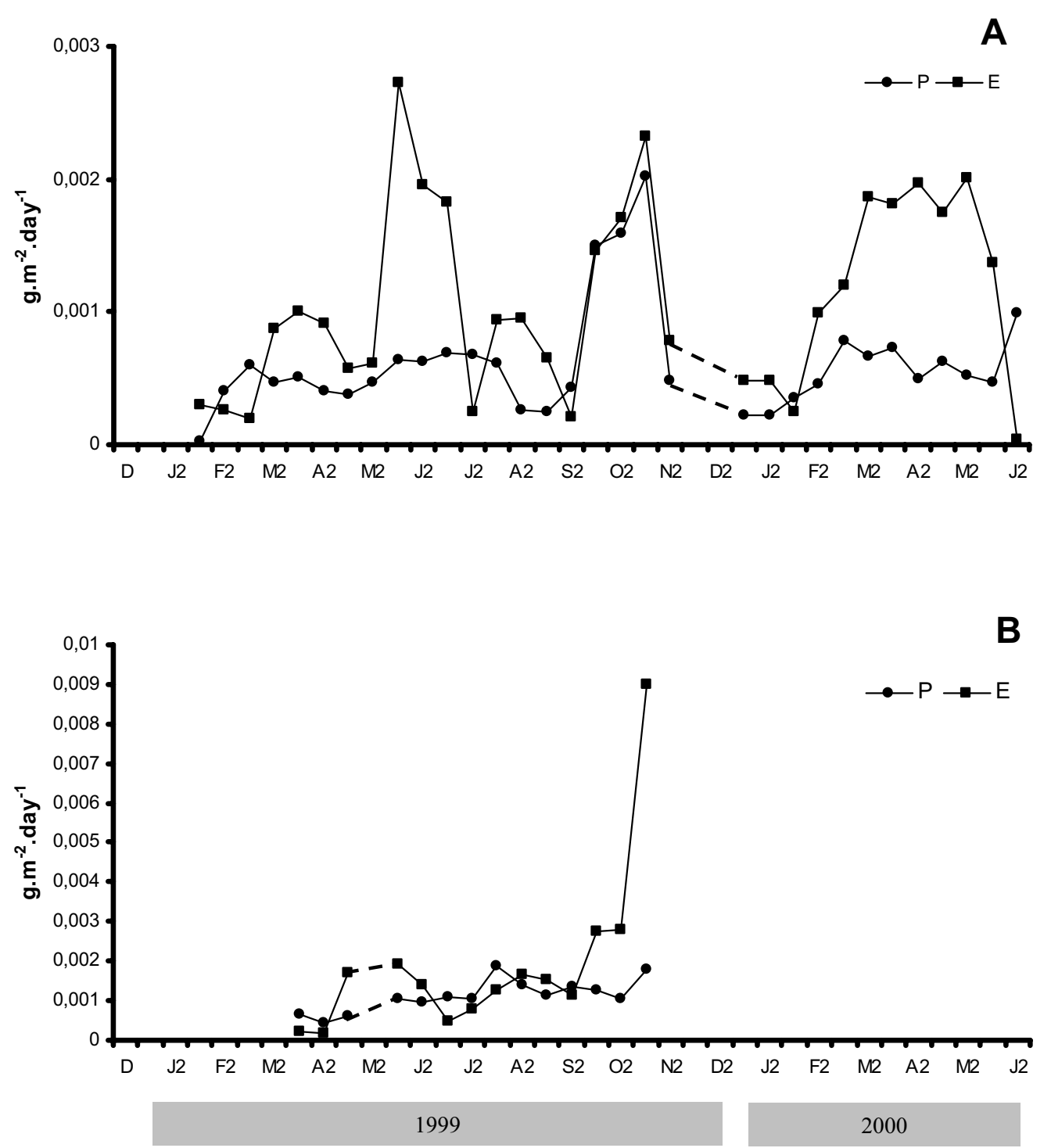

Fig. 8. Temporal variation of growth $(P)$ and elimination $(E)$ productions at the two study sites. (A) Atlantic, western coast of Portugal (Quiaios); (B) Mediterranean, north western coast of Tunisia (Zouara). Broken lines indicate probable evolution when data were insufficient due to sampling constraints.

(Williams, 1995; Tsubokura et al., 1997; Morritt, 1998). Nevertheless, the extremely drastic reduction of the population in Zouara during the winter may be apparent, and two alternative explanations could be considered: (a) a mass migration from the beach to the dunes, completely changing the horizontal distribution, as suggested by Marques et al. (2003) and (b) a displacement of the burrow zone into deeper layers where a more stable microclimatic habitat is achieved (Tsubokura et al., 1997), as observed in populations from SW France (Lagardère, 1966).

Talorchestia brito showed a more restricted and seaward distribution in comparison with Talitrus saltator's, which is consistent with previous observations on the French Atlantic coast (Fallaci et al., 1999) and in Zouara (Colombini et al., 2002; Scapini et al.,
2002). As suggested by these authors, this may reflect the presence of specific mechanisms of spatial and temporal behavioural plasticity between these sympatric species in relation to distinct trophic and microclimatic needs, possibly to avoid inter-specific competition. For instance, smaller body sizes and higher transpiration rates of several talitrid species, in comparison with $T$. saltator, may indicate lower desiccation tolerances, which could restrict their spatial distribution to areas of relatively higher moisture content (Morritt, 1987). Together with the differences in feeding preferences (Vader, 1970; Williams, 1978; Morritt, 1987) and migratory behaviour (Fallaci et al., 1999), this could explain differences in spatial distribution between $T$. saltator and $T$. brito (this study and Marques et al., 2003). 


\subsection{Reproductive period and sex ratio}

In the present study, the reproductive period was somewhat longer in Tunisia. In Netherlands, Talorchestia brito reproduces from June to September (Vader, 1970), and in SW France from March to October (Lagardère, 1966). Although these four data sets represent the only available information on this species' annual pattern of reproduction, a clear geographical pattern of variation emerges from their analysis. Recruitment periods are shorter at the northernmost part of $T$. brito European distribution, becoming longer as a function of a decrease in latitude. The combined seasonal changes in temperature and photoperiod may therefore act as major controlling factors regarding gonadal maturation and duration of reproductive period, as proposed for the sympatric species Talitrus saltator (e.g. Bregazzi and Naylor, 1972). The fact that the same pattern has been observed in other talitrid species reinforces this hypothesis. For instance, Orchestia mediterranea reproduces from April to October, in Great Britain, March to November in France, and throughout the year in the Morocco coast (Elkaïm et al., 1985), and $T$. saltator reproduces from May to September in the British Isles (Williams, 1978), from early March to late September in Portugal (Atlantic) and Italy (Mediterranean), and from late February to early November in Tunisia (Mediterranean) (Marques et al., 2003). Therefore, as argued by Gaston and Spicer (1998) regarding Orchestia gammarellus, it appears that large-scale distribution patterns do not correspond to "fixed" species physiology, and that ecologists should proceed with caution when attempting to make generalisations about the physiology of a species based on studies of a single population.

Deviations from the hypothetical Mendelian sex ratio $(1: 1)$ are a common feature among other amphipods, and thus not surprising in talitrids. A female biased sex ratio appears to be the most common situation among talitrids, as observed in Pseudorchestia brasiliensis (Cardoso and Veloso, 1996), Orchestia gammarellus (Jones and Wigham, 1993; Persson, 1999), Talitrus saltator (Williams, 1978) or Talorchestia capensis (Van Senus, 1988). The sex ratio in the Zouara population, with the exception of April/May, fits entirely in this pattern, but in Quiaios, during most of the study period, males were dominant in the population. The same was observed in Portuguese and Italian populations of T. saltator (Marques et al., 2003), but reasons for male biased sex ratios remain unclear. A non-homogeneous distribution of the two sexes between the beach and the dunes may occasionally explain the differences observed. Sex ratio deviations towards male dominance have also been observed in Atlantic and Mediterranean populations of $O$. gammarellus, Orchestia mediterranea, and Orchestia aestuarensis, and parasitic infestations by
Paramarteilia orchestiae (trans-ovarily transmitted parasite) were then indicated as a possible cause (GinsburgerVogel and Magniette-Mergault, 1981; Ginsburger-Vogel, 1989, 1991). This might be also an interesting hypothesis, but was not investigated.

Although sex ratio was predominantly male biased in Quiaios, females became dominant just before the peak of breeding activity in April/May and September/ October. This might be related with reproductive activity, with males copulating and dying quickly after ecdysis as observed in some Ampelisca species (e.g. Hastings, 1981; Carrasco and Arcos, 1984), or perhaps with a horizontal or vertical displacement of males. For instance, Williams (1995) found differences in the summer burrowing depth pattern of males and nongravid females versus gravid females of Talitrus saltator. Nevertheless, so far, no evidence of changes in zonation between sexes was found in Talorchestia brito.

\subsection{Influence of environmental factors}

Population density and the proportion of reproductive females were positively correlated with temperature, which appears therefore to play an important role in controlling breeding activity and recruitment. Changes in photoperiod might also be a factor of major influence, although this was not studied. The positive correlation found between the proportion of juveniles in the samples and sediment moisture suggests that, like in other talitrids, these are probably more sensitive to dehydration, hence concentrating closer to the recent high water mark (Morritt, 1987). No other significant correlations were found between population features and environmental factors, which is not surprising since it is often extremely difficult to establish significant statistical links between population dynamics and environmental controls from field data (e.g. Marsden, 1991b).

\subsection{Growth and life cycle}

The largest individuals were found in the Atlantic population, both in terms of weight and body length. This agrees with Bergmann's law (Fonseca et al., 2000), which states that individuals of higher latitude populations have larger maximum sizes than their counterparts of lower latitudes, suggesting the existence of a geographical temperature cline in body size.

Talorchestia brito's life span has not been estimated before. It was found that the Atlantic population lived longer (six to nine months at Quiaios) than the Mediterranean one (five to eight months at Zouara), which fits the pattern known from other talitrids: seven to eleven months in Portugal and six to eight months in Zouara for Talitrus saltator populations (Marques et al., 2003), five to nine months for a Moroccan population of Orchestia mediterranea (Elkaïm et al., 1985), 
twelve months for Orchestia gammarellus in the British Isles (Jones and Wigham, 1993), and six to eight months for O. mediterranea, Orchestia montagui and Platorchestia platensis in the Mediterranean (Louis, personal communication).

In both populations, male sexual differentiation after birth occurred earlier than in females (Table 4). Sexual differentiation of both males and females occurred later in Quiaios as compared to Zouara, respectively, one week for males and two weeks for females. It was estimated that females reached sexual maturity five weeks earlier at Zouara. As in Talitrus saltator (Marques et al., 2003), sexual differentiation and female sexual maturation after birth appear to take place earlier in Mediterranean populations in comparison to the Atlantic ones. Although there are no data available for northern European populations, this supports the existence of a cline variation, with adult size and life span increasing with latitude.

Both populations produced two generations per year, and apparently females from each cohort breed twice a year, which corresponds to a bivoltine life cycle, with iteroparous females (Table 4). On the other hand, northern European populations of Talorchestia brito present a much shorter reproductive season (from June to September) (Vader, 1970) than in Portugal and Tunisia, which suggests that other life cycle characteristics, namely voltinism, may also change as a function of latitude. Such kind of plasticity has in fact been observed in other talitrids-Talitrus saltator may vary from univoltine, in the British Isles (Williams, 1978) to bivoltine in Portugal, Italy and Tunisia (Marques et al., 2003) - and appears to be a common feature among amphipods (see Wildish, 1982; Sainte-Marie, 1991).

\subsection{Secondary production}

Higher values in growth production $(P)$ are usually related to increased temperature and metabolism, and also with more abundant food resources. In the present case, $P$ values were higher in autumn in both locations, although in Zouara such increase was rather modest. Peaks in abundance (Fig. 2) and in the percentage of juveniles in the population (Fig. 3A and B) may probably explain these results. The highest values in elimination production $(E)$ were reached from spring to autumn in Quiaios, and during autumn in Zouara, which is probably related to higher mortality rates involving older individuals after the reproductive effort, and juveniles as a response to winter nearness. Nevertheless, to a certain extent, seasonal changes in horizontal and vertical distributions may have hidden the real situation.

No other estimations of Talorchestia brito production are known, but the present results can be compared with other Talitrid species. The present estimations are of the same magnitude of values found by Cardoso and Veloso
(1996) in Brazilian sandy beaches for Pseudorchestoidea brasiliensis, but are lower than those estimated for Talitrus saltator in the same beaches (Marques et al., 2003), and for Talorchestia capensis in South Africa (Van Senus and McLachlan, 1986). Differences observed are especially relevant in the case of comparisons with T. saltator, since the overall methodology used (Marques et al., 2003) was the same, thus eliminating possible bias related with different methods of estimation. Results suggest diverse trophic needs and feeding habits reflecting on productivity as plausible causes. In fact, $T$. brito is known to feed mainly on Cyanophyceae and Diatomeae from the interstitial flora (Vader, 1970) and surf zone, while $T$. saltator feeds mainly on decomposing kelp and wrack stranded by waves and tides (Williams, 1978; Morritt, 1987).

Very similar $P / \bar{B}$ and $E / \bar{B}$ ratios were found for Talorchestia brito and Talitrus saltator (Marques et al., 2003) in both study sites, although the standing stock biomass was significantly lower in the case of $T$. brito, and much higher than that found for Talorchestia capensis by Van Senus and McLachlan (1986), and for Pseudorchestoidea brasiliensis by Cardoso and Veloso (1996). It was considered therefore useful to assess as to what extent these estimations were theoretically consistent. Wildish (1984) proposed a general equation for amphipods, which relates growth production, biomass and life span (expressed in years), allowing the ability to estimate $P / \bar{B}$ ratios from life span:

$\log _{10} P: \bar{B}=0.66-1.10$ ( $\log _{10}$ life span $)$.

Applying this equation to life spans estimated for the two studied populations, the resulting $P / \bar{B}$ ratio intervals show reasonable agreement with the field estimations.

As a whole, differences observed between Talorchestia brito Atlantic and Mediterranean populations, namely regarding morphometrical characteristics, reproduction periods, life spans, and growth rates, illustrate the existence of a geographical variation, with the Atlantic population presenting a slower life history.

\section{Acknowledgements}

The authors are indebted to all colleagues who assisted in field and laboratory work. This work was carried out in the scope of the research project "Bases for the integrated sustainable management of Mediterranean sensitive coastal ecosystems", funded by the European Union (IC18-CT98-0270), and of the Project (POCTI/CTA/36553/00) funded by the Portuguese FCT. The research complies with the current laws in the countries where it was conducted. We wish to thank the Delegate of Nefza-Zouara for allowing collection of the samples on the beaches. We also wish to thank Felicita Scapini, David J. Wildish and a third reviewer 
for their reviews and their helpful comments on the earlier versions of this manuscript.

\section{References}

Achouri, M.S., Charfi-Cheikhrouha, F., Marques, J.C., 2003. Biology, population structure, and field-growth rates of Porcellionides pruinosus (Brandt, 1833) (Isopoda, Oniscidea) at Garat Nâam (Kasserine, Tunisia). Crustaceana 75, 1241-1262.

Allen, K.R., 1971. Relation between production and biomass. Journal of the Fisheries Research Board of Canada 28, 1573-1581.

Borgioli, C., Martelli, L., Porri, F., D'Elia, A., Marchetti, G.M., Scapini, F., 1999. Orientation in Talitrus saltator (Montagu): trends in intrapopulation variability related to environmental and intrinsic factors. Journal of Experimental Marine Biology and Ecology 238, 29-47.

Bregazzi, P.K., Naylor, E., 1972. The locomotor activity rhythm of Talitrus saltator (Montagu) (Crustacea, Amphipoda). Journal of Experimental Marine Biology and Ecology 57, 375-391.

Bulnheim, H.P., Schwenzer, D.E., 1999. Allozyme variation and genetic divergence in populations of Talitrus saltator (Crustacea: Amphipoda) around the Atlantic coast, the Azores and the Canary islands. Cahiers de Biologie Marine 40, 185-194.

Cardoso, R.S., Veloso, V.G., 1996. Population biology and secondary production of the sandhopper Pseudorchestoidea brasiliensis (Amphipoda: Talitridae) at Prainha beach, Brazil. Marine Ecology Progress Series 142, 111-119.

Carrasco, F.D., Arcos, D.F., 1984. Life history and production of a cold-temperate population of the sublittoral amphipod Ampelisca araucana. Marine Ecology Progress Series 14, 245-252.

Cassie, R.M., 1954. Some uses of probability paper in the analysis of size-frequency distributions. Australian Journal of Marine and Freshwater Research 3, 513-522.

Cassie, R.M., 1963. Tests of significance for probability paper analysis New Zealand Sciences Review 6, 474-482.

Colombini, I., Aloia, A., Bouslama, M.F., El Gtari, M., Fallaci, M., Ronconi, L., Scapini, F., Chelazzi, L., 2002. Small-scale spatial and seasonal differences in the distribution of beach arthropods on the northern Tunisian coast. Are species evenly distributed along the shore? Marine Biology 140, 1001-1012.

Dahl, E., 1945. The amphipoda of the sound. Part I-terrestrial amphipoda. Lunds Universitets Arsskrift. N.F. Avd. 2 42, 1-53.

Dahl, E., 1952. Some aspects of the ecology and zonation of the fauna of sandy beaches. Oikos 4, 1-27.

David, R., 1936. Recherches sur la biologie et intersexualité de Talitrus saltator Mont. Buletin Biologique de la France et de la Belgique 70, 332-357.

De Matthaeis, E., Cobolli, M., Mattocia, M., Scapini, F., 1995. Geographic variation in Talitrus saltator (Crustacea, Amphipoda): biochemical evidence. Bolletino Zoologico 62, 77-84.

Elliot, J.M., 1977. Statistical Analysis of Samples of Benthic Invertebrates, second ed. Freshwater Biological Association, Science Publications, vol. 25, Titus Wilson and Son Ltd., Kendal, 160 pp.

Elkaïm, B., Irlinger, J.P., Pichard, S., 1985. Dynamique de la population d'Orchestia mediterranea L. (Crustacea, Amphipoda) dans l'estuaire du Bou Regreg (Morocco). Canadian Journal of Zoology 63, 2800-2809.

Fallaci, M., Aloia, A., Audoglio, M., Colombini, I., Scapini, F., Chelazzi, L., 1999. Differences in behavioural strategies between two sympatric talitrids (Amphipoda) inhabiting an exposed sandy beach of the French Atlantic Coast. Estuarine, Coastal and Shelf Science 48, 469-482.

Fialkowski, W., Rainbow, P.S., Fialkowski, E., Smith, D.B., 2000. Biomonitoring of trace metals along the Baltic coast of Poland using the sandhopper Talitrus saltator (Montagu) (Crustacea, Amphipoda). Ophelia 52, 183-192.
Fonseca, D.B., Veloso, V.G., Cardoso, R.S., 2000. Growth, mortality, and reproduction of Excirolana braziliensis Richardson, 1912 (Isopoda, Cirolanidae) on the Prainha Beach, Rio de Janeiro, Brazil. Crustaceana 73, 535-545.

Gaschütz, G., Pauly, D., David, N., 1980. A versatile program for fitting weight and seasonally oscillating length growth data. International Council for the Exploration of the Sea, Council Meeting Papers, G24, pp. 1-23.

Gaston, K.J., Spicer, J.I., 1998. Do upper thermal tolerances differ geographically separated populations of the beachflea Orchestia gammarellus (Crustacea: Amphipoda)? Journal of Experimental Marine Biology and Ecology 229, 265-276.

Ginsburger-Vogel, T., 1989. Determinisme des anomalies de sex-ratio à hérédité paternelle chez le crustacé amphipode Orchestia gammarellus Pallas. Invertebrate Reproduction and Development 16, 183-194.

Ginsburger-Vogel, T., 1991. Intersexuality in Orchestia mediterranea Costa, 1853, and Orchestia aestuarensis Wildish, 1987 (Amphipoda): a consequence of hybridisation or parasitic infestation. Journal of Crustacean Biology 11, 530-539.

Ginsburger-Vogel, T., Magniette-Mergault, F., 1981. The effects of temperature on sexual differentiation in the temperature sensitive thylogenic-intersexual offspring of Orchestia gammarellus (Pallas) (Amphipoda: Crustacea). International Journal of Invertebrate Reproduction 4, 39-50.

Harding, J.P., 1949. The use of probability paper for the graphical analysis of polymodal frequency distributions. Journal of the Marine Biological Association of United Kingdom 28, 141-153.

Hastings, M.H., 1981. The life cycle and productivity of an intertidal population of the amphipod Ampelisca brevicornis. Estuarine, Coastal and Shelf Science 12, 665-677.

Jones, M.B., Wigham, G.D., 1993. Reproductive biology of Orchestia gammarellus (Crustacea: Amphipoda) living in a sewage treatment works. Journal of the Marine Biological Association of United Kingdom 73, 405-416.

Jørgensen, S.E., Nielsen, S.N., Jørgensen, L.A., 1991. Handbook of Ecological Parameters and Ecotoxicology. Elsevier, Amsterdam. $1263 \mathrm{pp}$.

Lagardère, J.P., 1966. Recherches sur la biologie et l'écologie de la macrofaune des substrats meubles de la côte des Landes et de la côte Basque. Bulletin du Centre d'Etudes et de Recherches Scienifiques de Biarritz 6, 143-209.

Lillebø, A.I., Flindt, M.R., Pardal, M.A., Marques, J.C., 1999. The effect of macrofauna, meiofauna and microfauna on the degradation of Spartina maritima detritus from a salt marsh area. Acta Oecologica 20, 249-258.

Marques, J.C., Martins, I., Teles-Ferreira, C., Cruz, S., 1994. Population dynamics, life history, and production of Cyathura carinata (Krøyer) (Isopoda: Anthuridae) in the Mondego estuary, Portugal. Journal of Crustacean Biology 14, 258-272.

Marques, J.C., Gonçalves, S.C., Pardal, M.A., Chelazzi, L., Colombini, I., Fallaci, M., Bouslama, M.F., El Gtari, M., Charfi-Cheikhrouha, F., Scapini, F., 2003. Comparison of Talitrus saltator (Amphipoda, Talitridae) biology, dynamics, and secondary production in Atlantic (Portugal) and Mediterranean (Italy and Tunisia) populations. Estuarine, Coastal and Shelf Science 58S, 127-148 (DOI: 10.1016/S0272-7714(03)00042-8).

Marsden, I.D., 1991. Kelp-sandhopper interactions on a sand beach in New Zealand. II. Population dynamics of Talorchestia quoyana (Milne-Edwards). Journal of Experimental Marine Biology and Ecology 152, 75-90.

Marsden, I.D., 1991. Kelp-sandhopper interactions on a sand beach in New Zealand. I. Drift composition and distribution. Journal of Experimental Marine Biology and Ecology 152, 61-74.

McLachlan, A., Jaramillo, E., 1995. Zonation on sandy beaches. Oceanography and Marine Biology. An Annual Review 33, 305-335. 
Mezzetti, M.C., Naylor, E., Scapini, F., 1994. Rhythmic responsiveness to visual stimuli in different populations of talitrid amphipods from Atlantic and Mediterranean coasts: an ecological interpretation. Journal of Experimental Marine Biology and Ecology 181, 279-291.

Moore, P.G., Rainbow, P.S., Haynes, E., 1991. The beach-hopper Orchestia gammarellus (Crustacea: Amphipoda) as a biomonitor for copper and zinc: North Sea trials. The Science of the Total Environment 106, 221-238.

Morritt, D., 1987. Evaporative water loss under desiccation stress in semiterrestrial and terrestrial amphipods (Crustacea: Amphipoda: Talitridae). Journal of Experimental Marine Biology and Ecology 3, 145-157.

Morritt, D., 1998. Hygrokinetic responses of talitrid amphipods. Journal of Crustacean Biology 18, 25-25.

O'Hanlon, R.P., Bolger, T., 1997. Biomass, growth and secondary production of Arcitalitrus dorrieni (Crustacea: Amphipoda: Talitridae) at two sites in Co. Galway (Ireland). Journal of Zoology of London 241, 409-428.

Palluault, M., 1954. Notes écologiques sur le Talitrus saltator. Archives Zoology Expérimentale et Générale 91, 105-129.

Pardal, M.A., Marques, J.C., Metelo, I., Lillebø, A.I., Flindt, M.R., 2000. Impact of eutrophication on the life cycle, population dynamics and production of Ampithoe valida (Amphipoda) along an estuarine spatial gradient (Mondego estuary, Portugal). Marine Ecology Progress Series 196, 207-219.

Persson, L.E., 1999. Growth and reproduction in two brackish water populations of Orchestia gammarellus (Amphipoda: Talitridae) in the Baltic. Journal of Crustacean Biology 19, 53-59.

Rainbow, P.S., Moore, P.G., Watson, D., 1989. Talitrid amphipods (Crustacea) as biomonitors for copper and zinc. Estuarine, Coastal and Shelf Science 28, 567-582.

Sainte-Marie, B., 1991. A review of the reproductive bionomics of aquatic gammaridean amphipods: variations of life history traits with latitude, depth, salinity and superfamily. Hydrobiologia 223, $189-227$.

Scapini, F., Fasinella, D., 1990. Genetic determination and plasticity in the sun orientation of natural populations of Talitrus saltator. Marine Biology 107, 141-145.

Scapini, F., Quochi, G., 1992. Orientation in sandhoppers from Italian populations: have they magnetic orientation ability? Bolletino Zoologico 59, 437-442.

Scapini, F., Lagar, M.C., Mezzetti, M.C., 1993. The use of slope and visual information in sandhoppers: innateness and plasticity. Marine Biology 115, 545-553.
Scapini, F., Buiatti, M., De Matthaeis, E., Mattoccia, M., 1995. Orientation and heterozygosity of sandhopper populations in relation to stability of beach environments. Journal of Evolutionary Biology 8, 43-52.

Scapini, F., Porri, F., Borgioli, C., Martelli, L., 1999. Solar orientation of adult and laboratory-born juvenile sandhoppers: inter- and intra-population variation. Journal of Experimental Marine Biology and Ecology 238, 107-126.

Scapini, F., Aloia, A., Bouslama, M.F., Chelazzi, L., Colombini, I., El Gtari, M., Fallaci, M., Marchetti, G.M., 2002. Multiple regression analysis of the sources of variation in orientation of two sympatric sandhoppers, Talitrus saltator and Talorchestia brito, from an exposed Mediterranean beach. Behavioural Ecology and Sociobiology 51, 403-414.

Tsubokura, T., Goshima, S., Nakao, S., 1997. Seasonal horizontal and vertical distribution patterns of the supralittoral amphipod Trinorchestia trinitatis in relation to environmental variables. Journal of Crustacean Biology 17, 674-686.

Vader, W., 1970. Talorchestia brito Stebbing (Amphipoda, Talitridae) notes on distribution, taxonomy, and biology. Sarsia 42, 83-96.

Van Senus, P., 1988. Reproduction of the sandhopper, Talorchestia capensis (Dana) (Amphipoda, Talitridae). Crustaceana 55, 93-103.

Van Senus, P., McLachlan, A., 1986. Growth, production, and a partial energy budget for the Amphipod, Talorchestia capensis (Crustacea: Talitridae) in the Eastern Cape, South Africa. Pubblicaziones della Stazione Zoologica di Napoli I: Marine Ecology 7, 165-179.

Wildish, D.J., 1982. Evolutionary ecology and reproduction in gammaridean Amphipoda. International Journal of Invertebrate Reproduction 5, 1-19.

Wildish, D.J., 1984. Secondary production of four sublittoral, softsediment amphipod populations in the Bay of Fundy. Canadian Journal of Zoology 62, 1027-1033.

Wildish, D.J., 1988. Ecology and natural history of aquatic Talitroidea. Canadian Journal of Zoology 66, 2340-2359.

Williams, J.A., 1978. The annual pattern of reproduction of Talitrus saltator (Crustacea: Amphipoda: Talitridae). Journal of Zoology of London 184, 231-244.

Williams, J.A., 1995. Burrow-zone distribution of the supralittoral amphipod Talitrus saltator on Derbyhaven beach, Isle of Man-a possible mechanism for regulating desiccation stress? Journal of Crustacean Biology 15, 466-475. 